\title{
Chvála klasické komparatistiky a jejích přesahů
}

\author{
Ivo Pospíšil (Brno)
}

\begin{abstract}
Hana Voisine-Jechová: Spojizenia komparatystyczne z różnych stron. Redakcja i wstęp Elżbieta Konończuk i Elżbieta Sidoruk. Białystok: Uniwersytet v Białymstoku, Instytut Filologii Polskiej, Zakład Teorii i Antropologii Literatury, Towarzystwo Literackie im. Adama Mickiewicza, oddział Białystocki, 2016.
\end{abstract}

Česko-francouzská polonistka, bohemistka, slavistka a komparatistka Hana Voisine-Jechová (roč. 1927) zanechala pevnou stopu v evropské literární vědě, komparatistice a slavistice, ale také v literatuře jako takové: kromě literární vědy je to také překladatelka a hluboká, nápaditá básnírka a prozaička francouzská i česká (pseudonym Hana Sánerová; jde o její dívčí př́ijmení). ${ }^{1}$ Komparatistické aspekty měly i její Dějiny české literatury psané původně pro Francouze, později k nám přeložené Alešem Hamanem. Kniha francouzsko-české slavistky o české literatuře ukázala po dlouhém čase skutečné dějiny české literatury na srovnávacím pozadí, psané z jednoho, kompaktního zorného úhlu, nikoli kolektivní práce, sice podrobné, ale přece jen „slepence“ různých pohledů, názorů a sty- j lů, nebot̀ to, že by se poměrně velká skupina

1 O jejích věcech jsem psal vícekrát, mj.: Česká literatura a jeji mezinárodni souvislosti (K českému vydáni knihy Hany Voisine-Jechové Dějiny české literatury. Slavica litteraria 11, 2008, č. 1, s. 107-114; K směrově personalisticko-areálovým a komparativně kulturologickým dějinám národni literatury (Nad Ruskou moderní literaturou Milana Hraly a Dějinami české literatury Hany Voisine-Jechové). In: Od teorie jazyka k praxi komunikace. Sborník prací členů Katedry českého jazyka a literatury. Eds. Daniel Bína - Miloš Zelenka. České Budějovice: Pedagogická fakulta, Jihočeská univerzita, 2007, s. 19-30; Problém slovanské literatury viděné zvnějšku a zevnitřr. K českému vydáni knihy Hany Vosine-Je chové Dějiny české literatury. In: Genologické a medziliterárne štúdie. Priesečníky umenia a vedy. Acta facultatis philosophicae Universitatis Prešoviensis. Literárnovedný zborník 22. Zost. Viera Žemberová. Prešov: Filozofická fakulta Prešovskej univerzity, 2009, s. 183-192; Próza dnešního času, reflexe a samota (Hana Sánerová: Zlomky nepravého deníku. Praha: Andrej Štastný, 2013). Almanach Nitra 14, 2013. Editori a vedeckí redaktori: Jozef Vladár - Natália Muránska. Nitra: Mesto Nitra, Nitrianska odbočka Spolku slovenských spisovatelov, Filozofická fakulta Univerzity Konštantína Filozofa v Nitre, 2014, s. 293-296. lidí v zásadě shodla na pojetí české literatury i v důležitých detailech (nebot co jiného jsou detaily než často to nejpodstatnější $\mathrm{z}$ vývoje národní literatury) je podle mě nemožné. Dějiny literatury představují svého druhu „filozofii“ literárního vývoje, tedy musí implicitně obsahovat i teorii literárních dějin a právě to je v knize Hany Voisine-Jechové výrazně, i když nikoli deklarativně obsaženo. Především tu vyniká zásadní teze o nesamozřejmosti existence samostatné české literatury stejně jako českého národa. $\mathrm{V}$ tom je patrně síla i slabost české kulturní a duchovní komunity vůbec: její samozřejmé přesahování a její nesamozřejmá, přesně vymezená identita. Mohli bychom říci, že české země mají z hlediska duchovní kultury jako součást střední Evropy tytéž vlastnosti jako celý tento kulturně geopolitický areál: spojovat, prostupovat a prolínat, integrovat, při veškerém „stýkání a potýkáni“" spíše tolerantně přistupovat, i když právě to bylo v průběhu dějin nesčetněkrát napadáno a porušováno, až nakonec ve 20. století vyústilo v dramatických a tragických událostech obou světových válek a totalitních režimů. Tato koncepce české literatury ji ukazuje v reálném světle nezasaženém idealizací nebo umělými expurgacemi všelikého druhu jako těžce utvářenou, ale snad právě proto nepopiratelnou hodnotu: současně buduje pojetí vývoje české literatury jako relativně kompaktní a transcendující s kořeny v evropských tradicích, v kulturně jazykovém specifiku a v přesazích, jež sytily evropskou kulturu od raného středověku až po dnešní dobu, ovšem různým způsobem a s různou intenzitou. Kniha Hany VoisineJechové vydaná původně pro francouzského čtenáře a pak dobře přeložená a upravená i pro 
potřeby čtenáře českého, aniž by se setřel základní charakter původního pojetí, je velmi dobře napsaným a kvalitně koncipovaným dílem. Je to kniha, která usiluje ukázat českou literaturu a „filozofii““ jejího vývoje jako integrální součást evropského a světového vývoje a to je i dnes v této intenzitě poměrně vzácné.

Předkládaný soubor polsky psaných komparatistických studií vydaných v Białystoku shrnuje její obecné srovnávací úvahy i kontaktní srovnávací sondy $\mathrm{s}$ jádrem $\mathrm{v}$ plánu česko-polském, někdy i s pozadím francouzským a ruským (Dostojevskij). Jako žačka Karla Krejčího má však obecně evropský přehled, volně se pohybuje v různých literaturách a srovnává je tematologicky tvarově $s$ přesahy $k$ filozofii a antropologii literatury. Je charakteristické, že podstata svazku je založena na zkoumání cestopisu. Odkazuji k své studii, která svým rozpětím práci Voisine-Jechové připomíná. ${ }^{2}$ Odkazuji v ní mimo jiné na Vetterovu Islandii, jež byla za první Československé republiky editována v Brně. Postavil jsem tu cestopis proti stacionárním žánrům typu kroniky nebo moderněji románové kroniky: zatímco kroniková struktura reflektuje lidskou touhu po bezpečném ukotvení, cestopis reflektuje lidské hledání, tápání, neklid a touhu po změně a poznávání neznámého. Není divu, že právě tento žánr stál často u kolébky románového žánru. Cestopis ve své rudimentární, původní, prostě sdělovací, investigativní podobě může být i hádankou, která se řeší staletí: není zřejmá osobní nebo jiná motivace cesty. Může jí být prostá zvědavost nebo zvídavost nebo jiné, praktičtější účely; člověk mohl řešit cestou svou osobní, existenciálně vyhrocenou situaci, nebo mohl být pověřen nějakým tajným posláním. Linii cestopisu vedeme až do 21. století, kdy se radikálně mění jeho funkce. Také Voisine spojuje cestopis s existencialitou a zkoumá jeho podobu v letech 1760-1820.

Voisine-Jechová chápe literaturu a její vývoj především v řečišti literárních a uměleckých žánrů, stejně jako její pražský učitel. Vývojovou

2 POSPÍŠIL, Ivo: Problém tzv. cestopisu: statika/dynamika prostoru a lidská existence. Slavica litteraria, X 9, 2006, s. $155-170$. linii cestopisu tak vede od klasicismu $\mathrm{k}$ sentimentalismu a preromantismu a rozšiřuje půdorys svého zkoumání o srovnání s výtvarným uměním. Nepochybně s touto koncepcí je spojena i její analýza prostoru a času v literatuře (Žeromského Popely a obraz Španělska, Bruno Schulz 1892-1942, dnes takřka erbovní, ikonická postava desítek studií, zejména polských a německých, ale v poslední době i českých a slovenských, kubistický prostor, Zbigniew Herbert a perspektiva času v jeho poezii). Klíčovým tématem je také motivika literatury (vina a hřích v české a polské literatuře, titanismus, vizionářství, sen, humor a smích). Současně je zřejmé, že vidění literatury skrze kategorii literárních, resp. uměleckých směrů se koncentruje na romantismus a neoromantismus, což je také podporováno kategorií snění a vize a hlavně tím, že autorka vidí písemnictví jako širší celek umělecký a antropologický. Také si cením jejího zájmu o problém identity. Materiálové rozpětí je značné, ale přece jen se koncentruje spíše na romantismus a jeho předchůdce a deriváty (sentimentalismus, preromantismus, neoromantismus, moderna) a z nich vycházející existenciální cítění a chápání člověka a světě (Bruno Schulz, Herakles Otokara Fischera aj.) A co je ještě podstatnější: znovu se tu dokládá úzké sepětí komparatistiky a genologie, což je důležité zvláště v polském prostředí, nebot Poláci pěstují genologii takto systematicky vlastně jako jediní na světě.

Jak jsme napsali jinde ${ }^{3}$, není třeba komparatistickou tradici odsouvat na vedlejší kolej, tedy srovnávání na bázi kontaktologicko-genetické nebo typologické, teatrologické nebo tvarové, a nahrazovat je všeobjímající kulturologií. Jak ukázal vídeňský kongres komparatistické asociace v létě 2016, nelze toto pojetí vést až do slepé uličky, zvláště v konfrontaci různých civilizačních a kulturních okruhů a také ve sporu generací, nebot mladí badatelé už tyto metodologické jemnosti jako brzdící neovládají a začínají

3 POSPÍŠIL, Ivo: Literárni komparatistika: lákavá inovace, kvalitni tradice. Comparative Literary Studies: Alluring Innovation, High-Quality Tradition. Stil 8, 2009, s. 189208. 
jakoby na zelené komparatistické louce, pouze s nánosem módních diskursů bez přirozené návaznosti na 150 let trvající tradici. Takto nám česko-francouzská komparatistka s pevným ukotvením v evropské slavistice, zvláště bohemistice a polonistice, ukázala na nosnost tradičních př́stupů, jež však nejsou strnule tradicionalistické, stereotypní: v jejích reflexích ožívají sklony $\mathrm{k}$ existenciálním pojetím, rozšiřují se na umění výtvarné a oscilují mezi motivikou a morfologií literatury v poměrně sevřeném tvaru s jádrem v romantismu a jeho kontextech, jak je to pro polskou a dílem i českou literaturu a bádání v obou zemích typické. Co je však nejpodstatnější: v pojetí Hany Voisine-Jechové je motivika a tematika spojena s tvarem, formuje ho a je jím formována. Aspoň rámcově se jî podařilo, o čem kdysi dumal Bachtin: jak spojit problematiku literárního prostoru a času, i když jen na vymezeném materiálu. Dominance literárních směrů vede $\mathrm{k}$ přirozenému propojování literatury a dalších druhů umění a $\mathrm{k}$ vytváření generální poetiky a genologie. Nicméně to vše je uměřené, zdrženlivé, zdravě skeptické a tím ještě cennější. 